\title{
IMPACT OF HEATWAVE EVENTS ON LATENT AND SENSIBLE SURFACE HEAT FLUX AND FUTURE PERSPECTIVES IN SHALLOW LAKES BASED ON CLIMATE CHANGE MODELS
}

\author{
MARIA B. ALFONSO ${ }^{1 *}$, ANDREA S. BRENDEL ${ }^{1,2}$, \\ ALEJANDRO J. VITALE ${ }^{1,3}$, MARIA C. PICCOLO ${ }^{1,4}$ \\ ${ }^{1}$ Instituto Argentino de Oceanografía (IADO), Universidad Nacional del Sur (UNS)-CONICET, Florida 8000, \\ Complejo CCT CONICET Bahía Blanca, Edificio E1, B8000BFW, Bahía Blanca, Argentina. \\ ${ }^{2}$ Departamento de Agronomía, Universidad Nacional del Sur (UNS), \\ San Andrés 800, B8001FAN, Bahía Blanca, Argentina. \\ ${ }^{3}$ Departamento de Ingeniería Eléctrica y Computadoras, Universidad Nacional del Sur (UNS), \\ Av. Alem 1253, B8000CPB, Bahía Blanca, Argentina. \\ ${ }^{4}$ Departamento de Geografía y Turismo, Universidad Nacional del Sur, \\ 12 de Octubre $11984^{\circ}$ Piso, B8000CTX, Bahía Blanca, Argentina.
}

\begin{abstract}
According to model projections, increases in the frequency and intensity of heatwaves are expected all over the world. This study analyzed, for the first time, the effect of heatwaves events on long-term surface latent (LE) and sensible heat fluxes (H) from two shallow lakes: La Salada lake (LS - 39 $27^{\prime} \mathrm{S}, 62^{\circ} 42^{\prime} \mathrm{W}$ ) and Sauce Grande lake (SG - 38 $57^{\prime} \mathrm{S}, 61^{\circ} 24^{\prime} \mathrm{W}$ ). The main drivers of LE and $\mathrm{H}$ are wind speed and direction, relative humidity, and the difference between air and water temperature. We found that the daily values of both fluxes were highly fluctuating. Mean daily $\mathrm{H}$ values ranged between -309.4 to $200.5 \mathrm{~W} \mathrm{~m}^{-2}$ and -78.6 to $104.8 \mathrm{~W} \mathrm{~m}^{-2}$ in LS and SG, respectively. LE oscillated between -152 and $463.9 \mathrm{~W} \mathrm{~m}^{-2}$ and between -59.2 and $360.1 \mathrm{~W} \mathrm{~m}^{-2}$ in LS and SG, respectively. Both fluxes decreased with the passage of heatwaves events, presenting a high variation in its amplitude. Changes up to $96 \%$ in mean daily LE and $671 \%$ in mean daily H for LS and up to $25 \%$ in LE and $987 \%$ in $\mathrm{H}$ for SG were accounted in days with heatwaves respect to regular ones. We analyzed the air temperature increase for both lakes under future global warming scenarios (RCP 4.5 y RCP 8.5), expecting higher amplitudes in heat fluxes. These results contribute to the development of lake models, as well as to water resources management in the future.
\end{abstract}

\section{Impacto de las olas de calor en el flujo de calor superficial latente y sensible y perspectivas de futuro para las lagunas someras basadas en modelos de cambio climático}

RESUMEN. De acuerdo con las proyecciones de los modelos climáticos, se espera a nivel mundial un aumento en la frecuencia e intensidad de las olas de calor. Este estudio analiza, por primera vez, el efecto de los eventos de olas de calor en los flujos de calor latente (LE) y calor sensible (H) en dos lagunas someras: Laguna La Salada (LS - $39^{\circ} 27^{\prime} \mathrm{S}, 62^{\circ} 42^{\prime} \mathrm{W}$ ) y Laguna Sauce Grande ( $\mathrm{SG}-38^{\circ} 57^{\prime} \mathrm{S}, 61^{\circ} 24^{\prime} \mathrm{W}$ ). La velocidad y dirección del viento, la humedad relativa, y las diferencias de temperatura entre el aire y el agua determinaron los cambios en LE y H. Los valores diarios de ambas variables fueron altamente fluctuantes. Los valores medios diarios de $\mathrm{H}$ variaron entre 309,4 y $200,5 \mathrm{~W} \mathrm{~m}^{-2}$ y entre $-78,6$ y $104,8 \mathrm{~W} \mathrm{~m}^{-2}$ en LS y SG, respectivamente. Los valores medios diarios de LE variaron entre -152 y $463,9 \mathrm{~W} \mathrm{~m}^{-2}$ y entre $-59,2$ y $360,1 \mathrm{~W} \mathrm{~m}^{-2}$ en LS y SG, respectivamente. Ambos flujos disminuyeron con el paso de eventos de olas de calor, presentando una gran amplitud en los valores. En días con olas de calor comparados con días regulares se registraron cambios de hasta $96 \%$ en la media diaria de LE y $671 \%$ 
en la media diaria de $\mathrm{H}$ en LS y cambios de hasta 25\% en la media diaria de LE y $987 \%$ en la media diaria de $\mathrm{H}$ para SG. Finalmente, se analizó el futuro incremento de la temperatura del aire para ambas lagunas bajo dos escenarios de calentamiento global (RCP 4.5 y RCP 8.5), que permiten deducir mayores amplitudes de cambio en ambos flujos de calor. Estos resultados contribuyen al desarrollo de modelos para lagunas someras, y a las decisiones de manejo de los recursos hídricos en el futuro.

Key words: Sensible heat flux, Latent heat flux, High-frequency, Heatwave, Shallow lake, Instrumented buoy.

Palabras clave: flujo de calor sensible, flujo de calor latente, alta frecuencia, ola de calor, laguna somera, boya multi-paramétrica.

Received: 10 October 2019

Accepted: 31 March 2020

\begin{abstract}
* Corresponding author: María Belén Alfonso. Instituto Argentino de Oceanografía (IADO), Universidad Nacional del Sur (UNS)-CONICET, Florida 8000, Complejo CCT CONICET Bahía Blanca, Edificio E1, B8000BFW, Bahía Blanca, Argentina. E-mail address: mbalfonso@conicet-iado.gob.ar
\end{abstract}

\title{
1. Introduction
}

Lakes have a significant role in many environmental processes, like carbon dioxide and methane fluxes, acting as carbon sources or sinks, nutrients recycling and regional climate regulation, among others (Tranvik et al., 2009; Zhu et al., 2018). The regional climatic conditions and human activities in shallow lakes can affect the water level, limnological conditions, and, therefore, the ecological processes (Leira and Cantonati, 2008; Havens et al., 2016). The interaction between lakes and their adjacent atmospheric boundary layer is vital to understand the physical processes within them as the surface heat fluxes (Winder and Schindler, 2004; Woolway et al., 2015a). Among the drivers of the physical processes within lakes, the wind stress and turbulent mixing, together with the surface heating and cooling, are the most cited (Wüest and Lorke, 2003; Woolway et al., 2018). Lake temperature regulates many vital processes of lake ecosystems as carbon fluxes, ecosystem metabolism, nutrients dynamics, and seasonal plankton patterns, among others (Lagomarsino et al., 2011; Diovisalvi et al., 2015; Kraemer et al., 2017), and it is highly dependent of lake-atmosphere interactions. Furthermore, lakes presence regulates the regional climate, as water surface can change the microclimate of the surroundings by increasing humidity and decreasing temperature, which could change the local air circulation and enhances the airflow towards the outside of the water body (Diallo et al., 2018; Zhu et al., 2018).

Climate change produces effects on the thermal structure, heat budgets, and heat and energy fluxes at the air-water interface with consequences in the physicochemical characteristics and the biological community of lakes (Woolway et al., 2018). Water temperatures of many lakes worldwide have increased in the past decades (Fink et al., 2014). According to Arvola et al. (2010), these observed global changes in lake's heat content are attributed to increasing air temperatures. Besides, other factors as lake area, depth, residence time, optical properties, and landscape setting can influence the thermal characteristics of lakes (Arvola et al., 2010) and modify the response of the lake temperatures to changing meteorological conditions.

There are a large number of surface heat flux studies in lakes based on the eddy covariance method (Zhang and Liu, 2013; Shao et al., 2015) and also on the high-frequency measurement from instrumented buoys (Woolway et al., 2015b, 2018). Some studies have evaluated the effect of shortterm weather events as the passages of cold front (Zhang and Liu, 2013; Li et al., 2015), the intrusion 
of dry, cold air masses (Li et al., 2015), or the impact of climate-induced warming on heat fluxes (Fink et al., 2014). According to model projections, increases in the duration, intensity, and spatial extent of heatwaves in the short-term over most land regions are expected (Kirtman et al., 2013). In the context of climate change, the impact of climate extreme events, such as heatwaves, demonstrate the vulnerability of some ecosystems to climate variability (Field et al., 2013). Nevertheless, there is a lack of studies that evaluate the effect of heatwaves on latent and sensible heat fluxes on lakes.

Shallow and small lakes are the most abundant lake types globally and dominate the global area covered by continental waters (Downing et al., 2006). The Pampean Region in Argentina contains numerous shallow lakes, of which, those located in the Buenos Aires Province account for more than 13,500 shallow lakes with an area between 0.01 and $1000 \mathrm{~km}^{2}$ (Geraldi et al., 2011). Under the hypothesis that climate variability and particularly extreme events, as heatwaves, drive essential changes in the latent and sensible heat flux from shallow lakes, this study aims to describe, for the first time, the long-term surface sensible and latent heat flux and their drivers in two shallow lakes from the Pampean Region. Finally, the effect and contribution of heatwaves on the surface heat fluxes are analyzed.

\section{Materials and methods}

\subsection{Study sites}

This study comprises surface water temperature and meteorological observations from two shallow lakes situated in the Pampas Region in Argentina: La Salada lake (LS - 39 ${ }^{\circ} 27^{\prime}$ S, $62^{\circ} 42^{\prime}$ W) and Sauce Grande lake (SG - 38 $57^{\prime} \mathrm{S}, 61^{\circ} 24^{\prime} \mathrm{W}$ ) (Fig. 1). Their surface area ranges from 4 (LS) to 15.8 $\mathrm{km}^{2}$ (SG) and their maximum depths from 2.3 (SG) to $3.2 \mathrm{~m}$ (LS). The lakes are located in a temperature gradient from North (Sauce Grande) to the South (La Salada) (Alfonso et al., 2018). The climate in the region of SG is temperate; meanwhile, LS is cold temperate and mostly dry (Aliaga et al., 2017). Annual air temperature values are between 14 and $20^{\circ} \mathrm{C}$, with pronounced summers and winters. Wet and dry cycles characterize the Pampean region. The highest rainfalls occur typically in spring and summer, with an annual average of $369 \mathrm{~mm}$ for the LS area and $692 \mathrm{~mm}$ for the SG area (Aliaga et al., 2017). Prevailing winds in the region are from the NW, with a mean speed between 3.9 and $4.1 \mathrm{~m} \mathrm{~s}^{-1}$ (Aliaga et al., 2017).

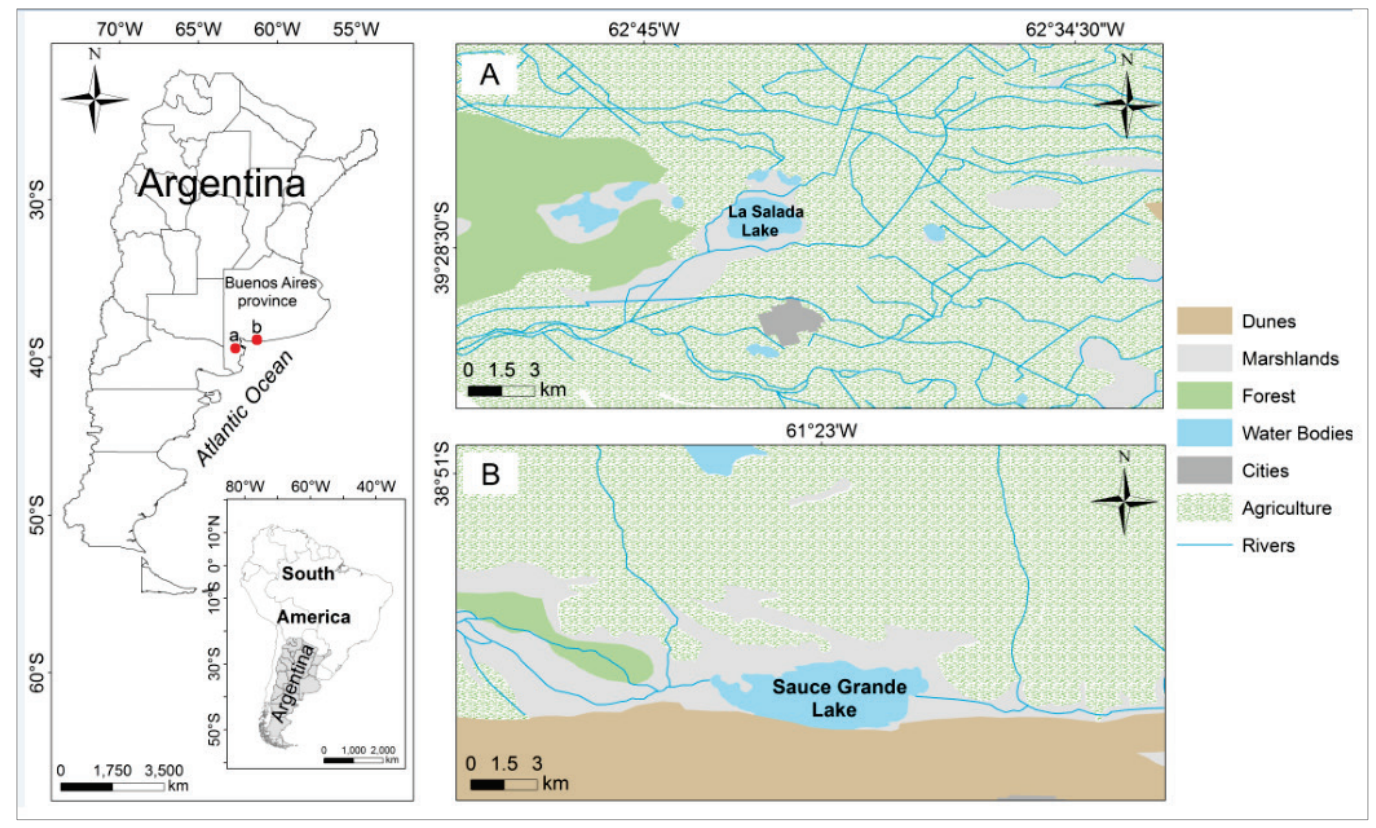

Figure 1. The geographic location of the study sites concerning their surroundings: A: La Salada lake location and land use; B: Sauce Grande lake location and land use. Modified from Alfonso et al. (2018). 


\subsection{High-frequency measurements and meteorological conditions}

We obtained high-frequency meteorological and surface water temperature data (every $10 \mathrm{~min}$ ) for four years with instrumented buoys (EMAC - Estación de Monitoreo Ambiental Costero) located in both lakes. Meteorological variables were measured at $2.10 \mathrm{~m}$ in height, including air temperature (Ta, $\left.{ }^{\circ} \mathrm{C}\right)$, relative humidity $(\mathrm{RH}, \%)$, wind speed $\left(\mathrm{U}, \mathrm{km} \mathrm{h}^{-1}\right)$, solar radiation $\left(\mathrm{Rsol}, \mathrm{W} \mathrm{m} \mathrm{m}^{-2}\right.$ ). Water temperature $\left(\mathrm{Tw},{ }^{\circ} \mathrm{C}\right.$ ) was measured at $0.5 \mathrm{~m}$ depth (Data are available at https://www.emac.iadoconicet.gob.ar/2019). For SG, we obtained Rsol data from the Coronel Dorrego meteorological station belonging to the National Institute of Agricultural Technology (INTA, for its name in Spanish). We also analyzed temporal atmospheric processes such as the passage of low and high-pressure centers during heatwave events at a regional scale by the analysis of daily synoptic maps from the National Meteorological Service (SMN, Argentina) available at https://www.smn.gob.ar/.

\subsection{Heat flux estimation}

We estimated the surface energy fluxes from lake buoy data with the Lake Heat Flux Analyzer script for MATLAB developed by Woolway et al. (2015b). The script is free to download at https:/github.com/ GLEON/HeatFluxAnalyzer. The calculated surface heat fluxes expressed in terms of the total surface heat flux (Qtot, $\mathrm{W} \mathrm{m}^{-2}$ ) are the flux of incoming short-wave radiation on the lake surface (Qsin), the reflected short-wave radiation (Qsr), the sensible (H) and the latent (LE) heat fluxes, the incoming long-wave (Qlin) and the outgoing long-wave radiation (Qlout):

$$
Q t o t=Q \sin +\text { Qlin }- \text { Qlout }-Q s r-L E-H
$$

The convention of signs applied to equation (1) was positive when the direction of heat transfer is from the lake to the atmosphere and negative when the opposite (Woolway et al., 2015b). The heat exchanges were estimated every $10 \mathrm{~min}$ and daily averaged. For more details about the equations used, see the methods of Woolway et al. (2015b). All the used abbreviations are presented in Table 1 to facilitate the lecture. One question that arose from the investigation was to determine which of the variables used in this study is the most important to determine the different heat fluxes. Therefore a Spearman (r) correlation analysis and a simple regression between LE, H, and the main meteorological variables were performed to identify those environmental factors that may have played the most significant role in heat fluxes with Infostat software (Di Renzo et al., 2018).

Table 1. Abbreviations used in the manuscript, their significance, and their units.

\begin{tabular}{|c|c|c|}
\hline Abbreviations & Significance & Unit \\
\hline HW & heatwave & \\
\hline LS & La Salada lake & \\
\hline SG & Sauce Grande lake & $\mathrm{m}$ \\
\hline Level & water level & ${ }^{\circ} \mathrm{C}$ \\
\hline Ta & air temperature & ${ }^{\circ} \mathrm{C}$ \\
\hline Tw & water temperature & $\mathrm{m} \mathrm{s}^{-1}$ \\
\hline $\mathrm{U}$ & wind speed & $\mathrm{m} \mathrm{s}^{-1}$ \\
\hline $\mathrm{U}_{10}$ & wind speed at 10 meters & ${ }^{\circ}$ \\
\hline $\mathrm{RH}$ & relative humidity & $\%$ \\
\hline $\mathrm{RH}{ }_{10}$ & relative humidity at 10 meters & $\mathrm{mm}^{-2}$ \\
\hline Rain & total rainfall & $\mathrm{W} \mathrm{m}^{-2}$ \\
\hline $\mathrm{H}$ & sensitive heat flux & $\mathrm{W} \mathrm{m}^{-2}$ \\
\hline LE & latent heat flux & \\
\hline
\end{tabular}




\begin{tabular}{|c|c|c|}
\hline Qtot & total surface heat flux & $\mathrm{W} \mathrm{m}^{-2}$ \\
\hline Qsin & incident short-wave radiation & $\mathrm{W} \mathrm{m}^{-2}$ \\
\hline Qsr & reflected short-wave radiation & $\mathrm{W} \mathrm{m}^{-2}$ \\
\hline Qlin & incoming long-wave radiation & $\mathrm{W} \mathrm{m}^{-2}$ \\
\hline Qlout & outgoing long-wave radiation & \\
\hline $\mathrm{CCSM}_{4}$ & community climate system model 4 & \\
\hline GHG & greenhouse gases & \\
\hline RCP 4.5 & representative concentration pathways at $4.5 \mathrm{~W} \mathrm{~m}^{-2}$ & \\
\hline RCP 8.5 & representative concentration pathways at $8.5 \mathrm{~W} \mathrm{~m}^{-2}$ & \\
\hline
\end{tabular}

\subsection{Future air temperature trends under future climatic scenarios}

To determine the possible future expected changes in Ta, we calculated the annual trend from a 20 years monthly mean time series (1998-2018) and for the near (2019-2039) and far future (20792099). To calculate trends, we applied the non-parametric Mann-Kendall test (Mann, 1945; Kendall, 1975) and to quantify the rates of change the Sen's slope estimator (Sen, 1968), using the "trend" package for R (R package version 1.1.1., Pohlert, 2018). We obtained the 1998-2018 time series from two weather stations, one located in the Bahía Blanca station $\left(38.44^{\circ} \mathrm{S}, 62.1^{\circ} \mathrm{W}\right)$, to describe the SG (National Weather Service (SMN, https://www.smn.gob.ar) and one in Hilario Ascasubi $\left(39.38^{\circ} \mathrm{S}\right.$, $62.62^{\circ} \mathrm{W}$ ), adjacent to La Salada (National Institute of Agricultural Technology, INTA, https://www.argentina.gob.ar/inta). We obtained the short- and long-term future series with a climate model database from the Centro de Investigaciones del Mar y la Atmosfera (CIMA) (http://3cn.cima.fcen.uba.ar). We used the annual mean temperature of the Community Climate System Model 4 (CCSM4) of the National Centre for Atmospheric Research (NCAR, USA) as this resulted in the best from 24 climate models from CMIP5 (Coupled Model Intercomparison Project 5) and CLARISLPB (A Europe-South America Network for Climate Change Issues and Impacts Assessment - La Plata Basin Project), assessed for the present time in the region after a quantile-mapping bias correction using observations from the Climate Research Unit (CRU). We used two Representative Concentration Pathways (RCP) for the emission of greenhouse gases (GHG): RCP 4.5 that represents a mitigation scenario, which stabilizes radiative forcing at $4.5 \mathrm{~W} \mathrm{~m}^{-2}$ and RCP 8.5 that represents a rising scenario with a radiative forcing of $8.5 \mathrm{~W} \mathrm{~m}^{-2}$ at 2100 .

\section{Results and discussion}

\subsection{Annual and inter-annual variations in sensible and latent heat}

Annual mean values and standard deviation of the main meteorological and limnological variables measured during the study period are presented in Table 2 and daily mean values are presented in Fig. 2 and Fig. 3. Data gaps were due to instrument failures and cleaning-calibration procedures. Both lakes have a seasonal fluctuation of the Ta, Tw and $\mathrm{RH}_{10}$ (Figs. 2 and 3). Mean wind speed at 10 meters $\left(\mathrm{U}_{10}\right)$ was higher in LS (Table 2, Fig. 2c), reaching values up to $35 \mathrm{~m} \mathrm{~s}^{-1}$ whereas in SG it presented values up to $20 \mathrm{~m} \mathrm{~s}^{-1}$ (Fig. 3c). Annual cycles of LE and $\mathrm{H}$ in both lakes are represented by the daily means derived from the 10 minutes data (Figs. 2a and 3a). In each site, LE followed a clear seasonal cycle; $\mathrm{H}$ did not present a clear temporal trend (Figs. 2a and 3a) as it was observed in previous studies in temperate lakes (Li et al., 2015; Woolway et al., 2015a, 2018; Zhang and Liu, 2013; Zhao and Liu, 2018). The warmer months (October-March) presented maximum LE values; meanwhile, the colder months (April- September) the minimum ones (Figs. 2a and 3a). A study developed in several temperate lakes also found that $\mathrm{H}$ followed a less pronounced seasonal trend, with higher $\mathrm{H}$ values during autumn as a result of the greater air-water temperature difference (Woolway et al., 2018). We did not observe it in LS and SG lakes because of the lesser water heat storage of temperate shallow lakes in comparison with deep temperate lakes. 

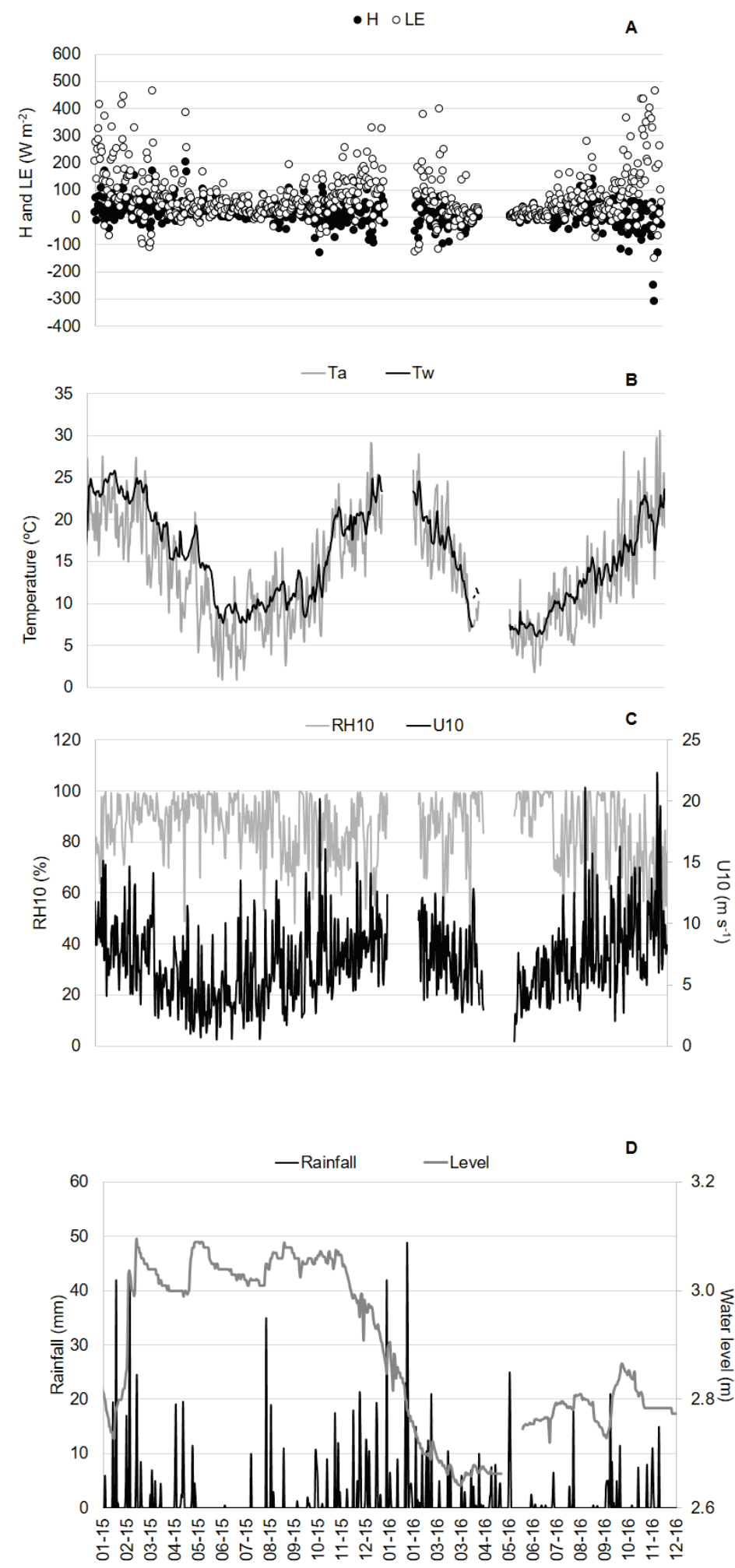

Figure 2. Mean daily values of A: latent (H) and sensible heat (E), B: Air (Ta) and water temperature (Tw), $C$ : Wind speed $\left(U_{10}\right)$ and relative humidity $\left(R H_{10}\right)$ at 10 meters and D: rainfall and water level in La Salada lake during the study period. 

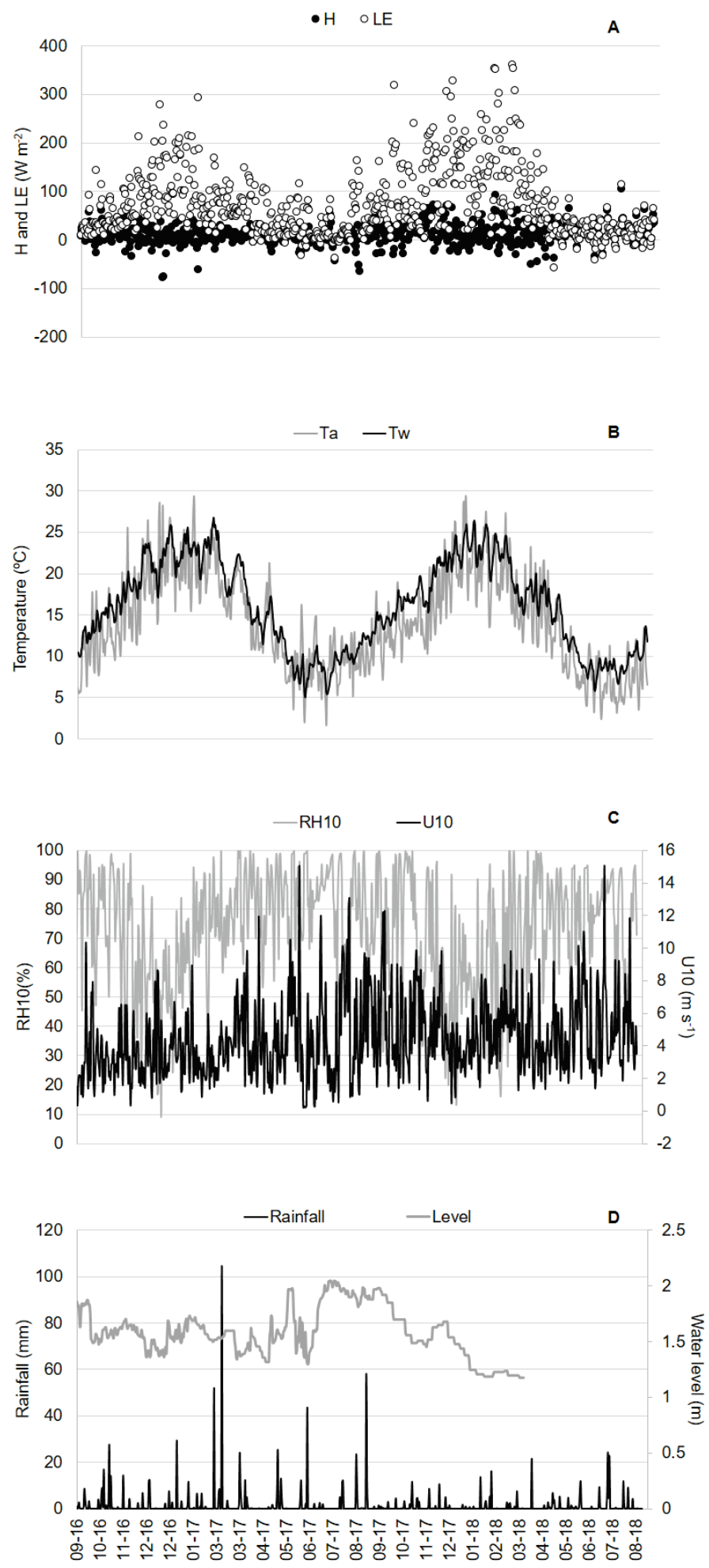

Figure 3. Mean daily values of A: latent (H) and sensible heat (E), B: Air (Ta) and water temperature (Tw), $C$ : Wind speed $\left(U_{10}\right)$ and relative humidity $\left(R H_{10}\right)$ at 10 meters and $D$ : rainfall and water level in Sauce Grande lake during the study period. 
Table 2. Mean annual values and standard deviation of lake area (Area), water level (Level), air temperature $(T a)$, water temperature $(T w)$, wind speed $\left(U_{10}\right)$, relative humidity $\left(H R_{10}\right)$, sensitive flux $(H)$ and latent flux $(L E)$, and total rainfall (Rain) in La Salada and Sauce Grande during the study period.

\begin{tabular}{|l|c|c|c|c|}
\hline Variables & $\begin{array}{c}\text { LS } \\
\mathbf{2 0 1 5}\end{array}$ & $\begin{array}{c}\text { LS } \\
\mathbf{2 0 1 6}\end{array}$ & $\begin{array}{c}\text { SG } \\
\mathbf{2 0 1 6 - 2 0 1 7}\end{array}$ & $\begin{array}{c}\text { SG } \\
\mathbf{2 0 1 7 - 2 0 1 8}\end{array}$ \\
\hline Level (m) & $3.0 \pm 0.08$ & $2.8 \pm 0.06$ & $1.6 \pm 0.2$ & $1.5 \pm 0.2$ \\
\hline Ta $\left({ }^{\circ} \mathbf{C}\right)$ & $13.9 \pm 6.2$ & $13.9 \pm 6.4$ & $14.6 \pm 5.7$ & $13.8 \pm 5.9$ \\
\hline Tw $\left({ }^{\circ} \mathbf{C}\right)$ & $16.3 \pm 5.5$ & $14.5 \pm 5.3$ & $15.9 \pm 5.6$ & $15.9 \pm 5.2$ \\
\hline $\mathbf{U}_{\mathbf{1 0}}\left(\mathbf{m ~ s}^{-\mathbf{1}}\right)$ & $6.6 \pm 3.3$ & $7.5 \pm 3.3$ & $3.9 \pm 2.4$ & $5.0 \pm 2.3$ \\
\hline RH $_{10}(\mathbf{\%})$ & $86.8 \pm 11.3$ & $83.9 \pm 15.6$ & $74.8 \pm 18.4$ & $70.9 \pm 20.1$ \\
\hline Rain $(\mathbf{m m})$ & 615 & 495 & 671 & 382 \\
\hline H $\left(\mathbf{W} \mathbf{~ m}^{-2}\right)$ & $20.5 \pm 39.95$ & $1.9 \pm 44$ & $6.83 \pm 17.2$ & $14.2 \pm 21.7$ \\
\hline $\mathbf{L E ~}\left(\mathbf{W} \mathbf{~ m}^{-2}\right)$ & $76.8 \pm 86.9$ & $66.7 \pm 99.8$ & $59.9 \pm 53.8$ & $81.5 \pm 80.3$ \\
\hline
\end{tabular}

Inter-annual variations in LE and $\mathrm{H}$ values in both lakes were detected (Table 2). For LS, a decrease of $13.2 \%$ for LE and $90.7 \%$ in $\mathrm{H}$ from 2015 to 2016 was found. Meanwhile, for SG, an increase of $107.9 \%$ for $\mathrm{LE}$ and $81.5 \%$ in $\mathrm{H}$ from the first to the second period was observed. Furthermore, $\mathrm{LE}$ and $\mathrm{H}$ daily values were highly fluctuating (Figs. $2 \mathrm{a}$ and 3a). For LS, mean daily $\mathrm{H}$ ranged between -309.4 and $200.5 \mathrm{~W} \mathrm{~m}^{-2}$ day $^{-1}$ and mean daily LE between -152 and $463.9 \mathrm{~W} \mathrm{~m}^{-2}$ day ${ }^{-1}$ (Fig. 2a). Meanwhile, for SG, mean daily $\mathrm{H}$ ranged between -78.6 and $104.8 \mathrm{~W} \mathrm{~m}^{-2}$ day $^{-1}$ and mean daily LE between -59.2 and 360.1 $\mathrm{W} \mathrm{m}^{-2}$ day $^{-1}$ (Fig. 3a). The LE and $\mathrm{H}$ amplitudes for both lakes were higher than those cited in other lakes (Li et al., 2015; Woolway et al., 2015a, 2018; Zhang and Liu, 2013; Zhao and Liu, 2018). Notably, there were several times when daily LE and $\mathrm{H}$ presented high negative values in both lakes, mainly in warmer months (Fig. 3). After a rigorous analysis of these events, most of them coincides with mean daily Ta values greater than $27^{\circ} \mathrm{C}$ for consecutive days, which are associated with heatwaves events. To analyze in detail this process, we focus the following sections on the warmer months for both lakes.

\subsection{Effect of heatwave events on heat flux diurnal variations}

We based our analysis on the definition of a heatwave (HW) as an event when maximum daily Ta was greater than $32{ }^{\circ} \mathrm{C}$ for three or more days during the warm season (October-March) (Rusticucci et al., 2016). These values correspond to the mean daily $90^{\text {th }}$ percentile calculated over the warm season of the year based on a 29 years' time series for Argentina (Rusticucci et al., 2016). LS presented two HW events during 2015 (5-7 March and 24-27 December) and four during 2016 (21-23 February, 2830 March, 22-24 November, and 15-31 December). Meanwhile, SG presented two HW events during the first period of study 2016-2017 (27-30 December 2016 and 27-29 January 2017) and four during the second period 2017-2018 (8-12 January, 20-22 January, 3-8 February, 16-18 February of 2018). There were also several times when maximum Ta was above $32^{\circ} \mathrm{C}$, but not for three consecutive days, so we do not include these events in the analysis.

The diurnal variations in $\mathrm{LE}, \mathrm{H}, \mathrm{Tw}, \mathrm{Ta}, \mathrm{RH}_{10}, \mathrm{U}_{10}$, and wind direction before, during, and after a HW event for each lake are presented in Figures 4 and 5. These two HW events were randomly selected as examples from all the HW events registered. In LS, when a high-pressure center locates over the lake area, a four days HW event on $24^{\text {th }}$ December 2015 (Fig. 4) was registered. A dry and warm air mass dominated the region, causing significant changes in the meteorological conditions and the magnitudes of LE and $\mathrm{H}$ fluxes (Fig. 6a). The previous days to the HW, Ta, and Tw were already high, accounting an increase above $18{ }^{\circ} \mathrm{C}$ in maximum Ta and above $6{ }^{\circ} \mathrm{C}$ in maximum Tw (Fig. 4b). Also, we observed an increase in $\mathrm{RH}_{10}$ and a decrease in water level (Fig. 4c, d) generated not only by the warm temperatures but also for the strong winds that mixed the lake waters, increasing evaporation. $U_{10}$ was always close to $18 \mathrm{~m} \mathrm{~s}^{-1}$ from NW direction (Fig. $4 \mathrm{c}, \mathrm{e}$ ), but being the $\mathrm{RH}_{10}$ close to the saturation point, 
originated low values of LE. The high gradient between Tw-Ta originated negatives $\mathrm{H}$ during the HW event (Fig. 4a). Previous studies also associated changes in LE with changes in $\mathrm{RH}_{10}$ and $\mathrm{U}_{10}$, and changes in $\mathrm{H}$ with changes in Tw-Ta and $\mathrm{U}_{10}$ (Li et al., 2015; Woolway et al., 2015a, 2018; Zhang and Liu, 2013; Zhao and Liu, 2018).

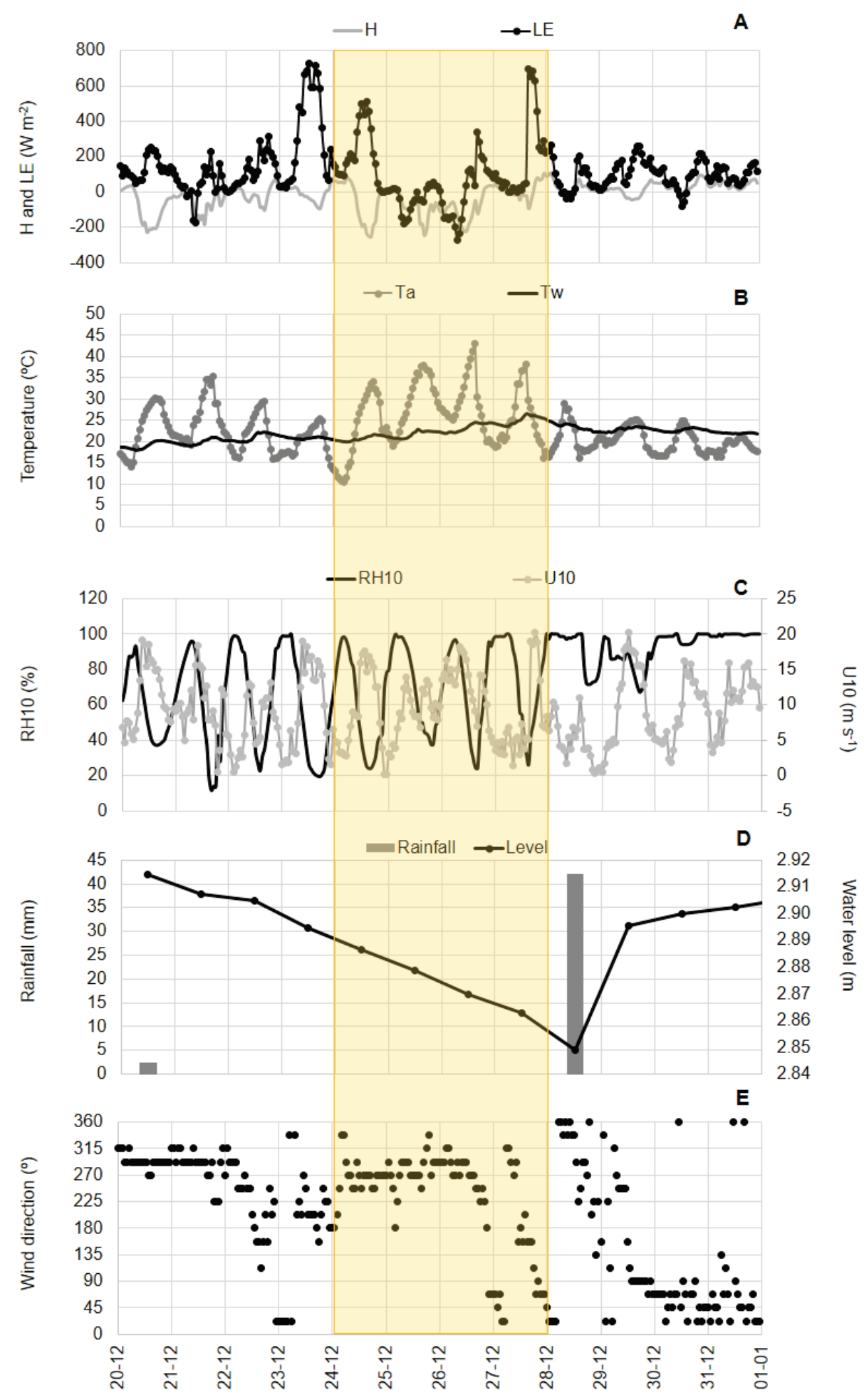

Figure 4. Variation of the measured parameters before, during, and after the passage of a heatwave in A: hourly surface latent and sensible heat, $B$ : air and water temperature, $C$ : Windspeed and relative humidity D: and E: wind direction in La Salada lake during December 2015. 


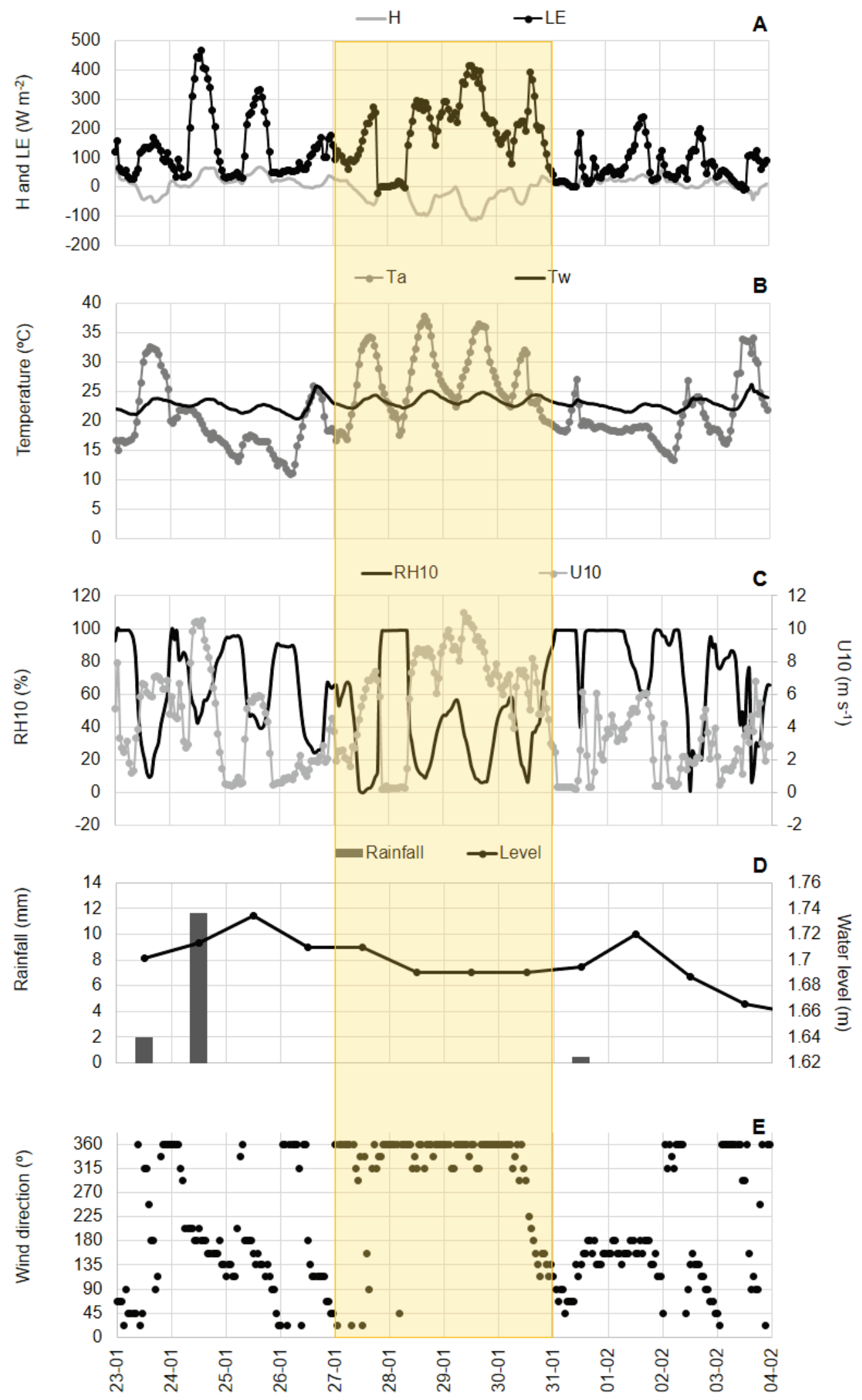

Figure 5. Variation of the measured parameters before, during and after the passage of a heatwave in A: the surface latent and sensible heat, B: air and water temperature, $C$ : Wind speed and relative humidity D: rainfall and water level and E: wind direction in Sauce Grande lake during January 2017. 
After the HW, the intrusion of a low-pressure system with a relatively cold air mass from the South (Fig. 6b) decreased the temperatures. The precipitation was $42 \mathrm{~mm}$, originating an increase of $\mathrm{RH}_{10}$ to saturation values and a rise in the water level (Fig. 4d). $\mathrm{U}_{10}$ was strong with velocities of $15 \mathrm{~m}$ $\mathrm{s}^{-1}$. This situation triggered an increase in LE and $\mathrm{H}$ returning to positive values, with a significant pulse in LE as soon as the wind direction changed from NW to SSE on $27^{\text {th }}$ December (16-17 h), reaching values over $600 \mathrm{~W} \mathrm{~m}^{-2}$. Previous studies also registered increases in $\mathrm{LE}$ and $\mathrm{H}$ after the intrusion of cold, dry air masses with strong wind speed values (Zhang and Liu 2013, Li et al., 2015).
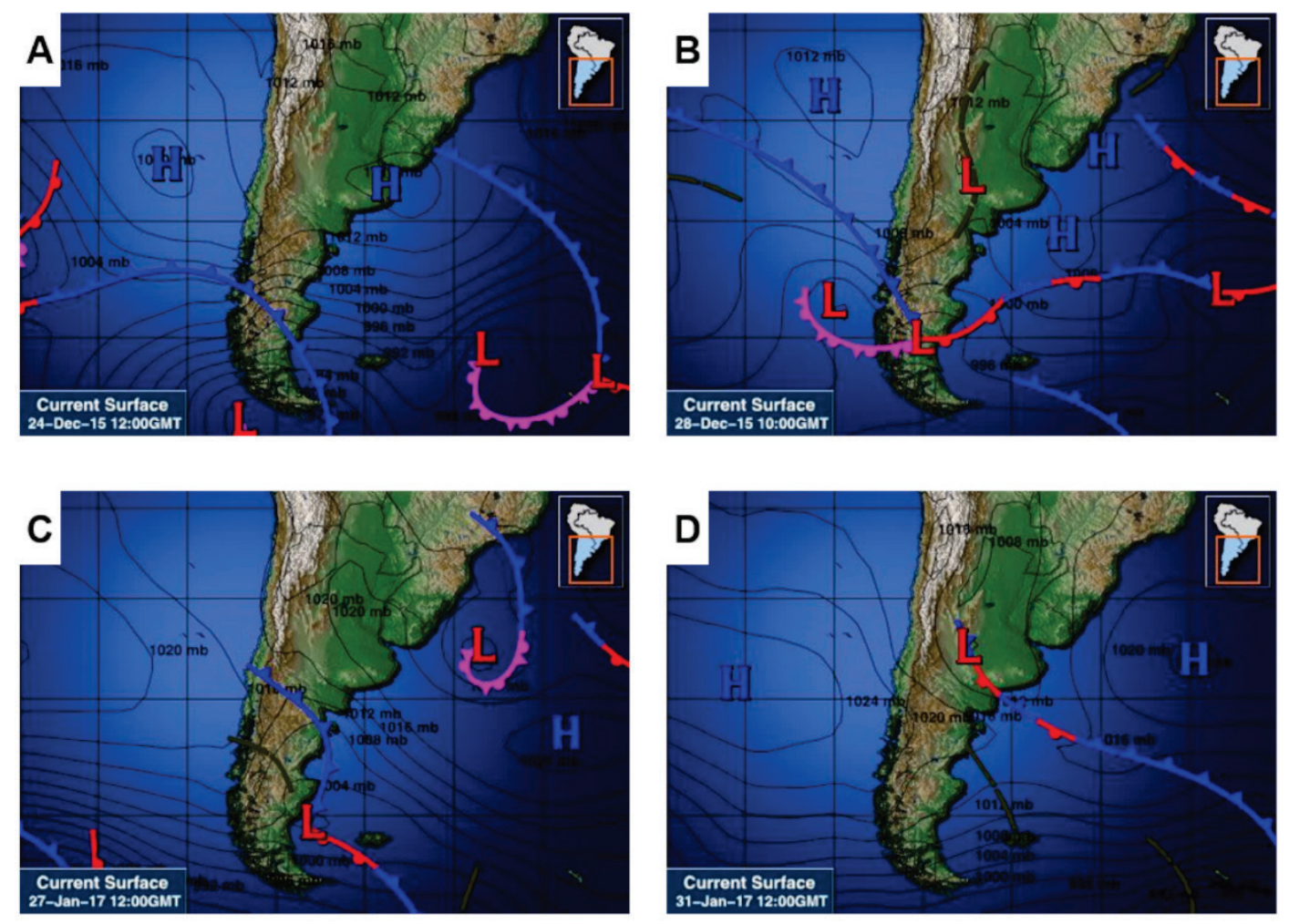

Figure 6. Synoptic maps for the study area during December 2015 (A and B) and January 2017 (C and D) (Source: https://www.wunderground.com/intellicast).

In the case of SG, from $27^{\text {th }}$ January 2017, a three days HW event was registered (Fig. 5), when a dry, hot air mass flowed over the lake area, causing significant changes in the LE and $\mathrm{H}$ fluxes and meteorological variables (Fig. 6c). In the previous days, both $\mathrm{Ta}$ and $\mathrm{Tw}$ presented values below the average for the season, and along the $\mathrm{HW}$, the Ta and $\mathrm{Tw}$ increased $11.7^{\circ} \mathrm{C}\left(37.2^{\circ} \mathrm{C}\right.$ maximum value $)$ and $3{ }^{\circ} \mathrm{C}\left(25.1{ }^{\circ} \mathrm{C}\right.$ maximum value) respectively. A significant decrease in $\mathrm{RH}_{10}$ and water level (Fig. $5 \mathrm{c}, \mathrm{d}$ ) and an increase in $\mathrm{U}_{10}$ reaching values up to $10 \mathrm{~m} \mathrm{~s}^{-1}$ from $\mathrm{N}$ direction (Fig. $5 \mathrm{c}$, e) were observed. These changes allowed a decrease in $\mathrm{H}$ values reaching values near $-113 \mathrm{~W} \mathrm{~m}^{-2}$, meanwhile LE increased reaching maximum values up to $410 \mathrm{~W} \mathrm{~m}^{-2}$ (Fig. 5a). After the event, followed an intrusion of a lowpressure center (on $30^{\text {th }}$ January) flowing from the sea on the SG area, changing LE and H rates.

According to these results, in $\mathrm{LS}$, the changes in $\mathrm{RH}_{10}$, Ta, and $\mathrm{Tw}$ ruled the $\mathrm{LE}$ and $\mathrm{H}$ variations; meanwhile, in $\mathrm{SG}$, the low $\mathrm{RH}_{10}$ and the strong $\mathrm{U}_{10}$ played a significant role in determining the fluxes. The difference among sites could be explained as LS is located in the cold temperate region, next to the Patagonian Region, where wind speeds are among the highest on a global scale (Guozden et al., 2018), therefore $\mathrm{U}_{10}$ is regularly strong (Table 2). Meanwhile, $\mathrm{SG}$ is in a temperate region with an annual mean $\mathrm{U}_{10}$ that do not exceed $5 \mathrm{~m} \mathrm{~s}^{-1}$ during the study period (Table 2). Previous studies cited that LE is ruled mainly by the changes in $\mathrm{U}_{10}$ and $\mathrm{RH}_{10}$, meanwhile, $\mathrm{H}$ is ruled by changes in $\mathrm{U}_{10}$ and $\mathrm{Tw}-\mathrm{Ta}$ (Zhang and Liu, 2013; Li et al., 2015; Woolway et al., 2015a), so, the results found in LS serve as an example of 
how $\mathrm{LE}$ and $\mathrm{H}$ behave in sites where $\mathrm{U}_{10}$ are always high, but other parameters define the sign of the fluxes. The fact that LS is twice deeper than SG explains the differences among lakes in the lag time between Ta and Tw (Table 2, Figs. $4 \mathrm{~b}$ and $5 b$ ).

\subsection{Effect and contribution of heatwaves in the diurnal and annual latent and sensible heat}

Mean diurnal cycles for $\mathrm{H}$ and LE during HW, and no heatwave events are presented in Figure 7 for the months with HW. A clear differentiation on the fluxes magnitudes along the day was observed (Fig. 7). In LS, LE was significantly correlated and responded to changes in $U_{10}$ and the $H_{10}(r=0.39$ $\mathrm{p}<0.01$ and $\mathrm{r}=-0.34 \mathrm{p}<0.01$ respectively) in accordance with studies in temperate lakes (Woolway et al., 2018). As in other studies, the diurnal cycle in $H$ was opposite to $U_{10}$, to which is related and responded to the difference in temperature between air and water. According to Woolway et al. (2018), this suggests that the Tw-Ta difference is the main driver of the diurnal variability of $\mathrm{H}$ and that the magnitude of the Tw-Ta outweighs the opposite influence of $U_{10}$ at diurnal timescales. This result is supported by the significant correlation with $\mathrm{Ta}$ and $\mathrm{Tw}(\mathrm{Ta}=-0.38 \mathrm{p}<0.01)$. In general, LE and $\mathrm{H}$ values decreased to negative values with the passage of HW events, presenting a higher variation amplitude (Fig. 7 a-f). Decreases of more than $180 \mathrm{~W} \mathrm{~m}^{-2}$ in LE (Feb-2016) and $69 \mathrm{~W} \mathrm{~m}^{-2}$ in $\mathrm{H}$ (Dec2015) were observed with the passage of HW in LS (Fig. 7 a-f).

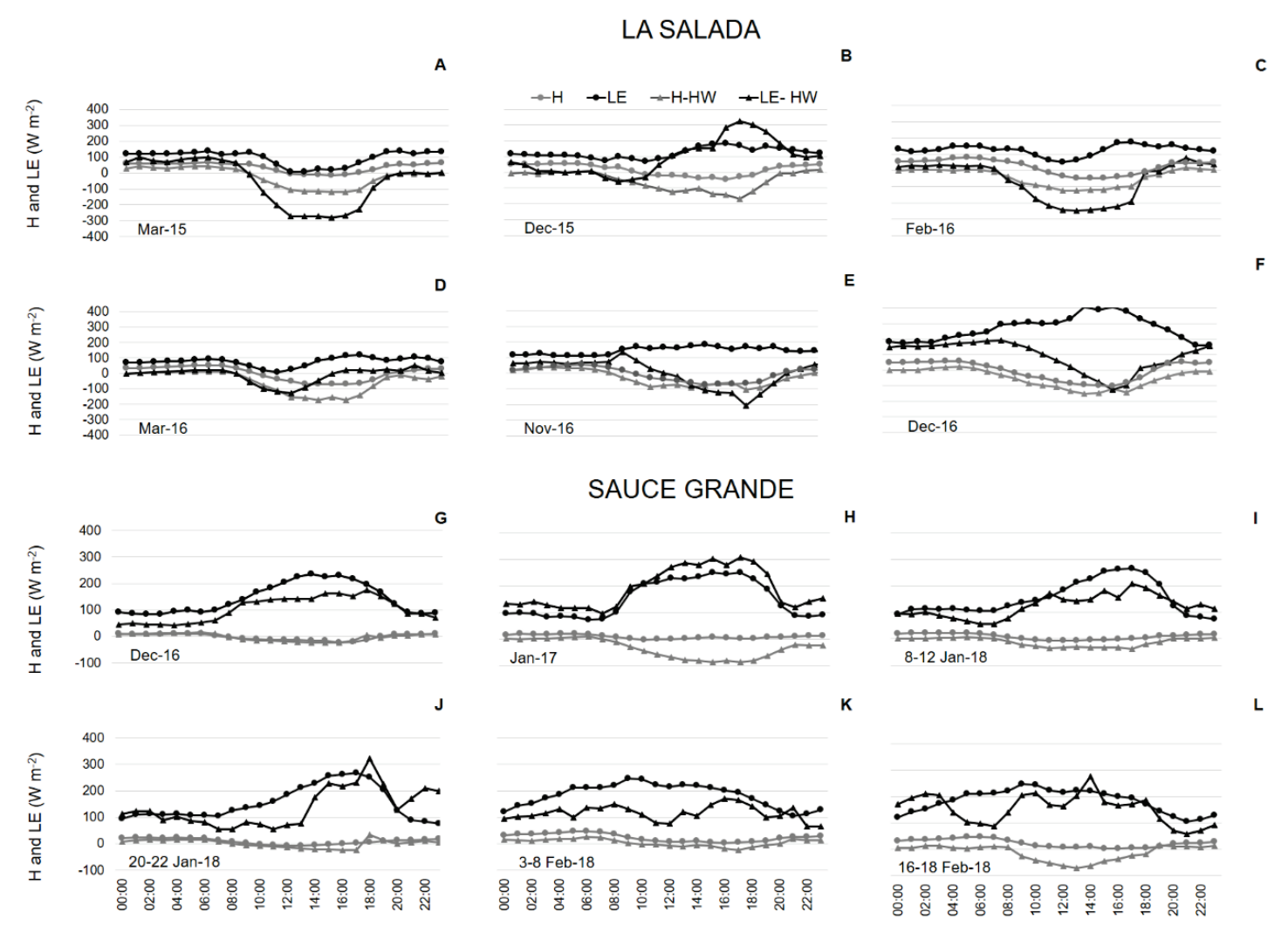

Figure 7. Monthly mean diurnal cycles of sensible heat $(H)$ and latent heat (LE) during selected heatwave events (H-HW and LE-HW) and during regular days in La Salada Lake (A-F) and Sauce Grande Lake (G-L) during the study period.

In SG lake, the increase in LE followed the increase in $\mathrm{U}_{10}(\mathrm{r}=0.39, \mathrm{p}<0.01)$; meantime $\mathrm{H}$ followed the pattern determined by the difference in temperature values $(\mathrm{r}=0.38, \mathrm{p}<0.01)$. This pattern was consistent during the warmer season, with LE values between $36.03 \mathrm{~W} \mathrm{~m}^{-2}$ (Oct-2016) and 287.31 $\mathrm{W} \mathrm{m}^{-2}$ (Dec-2017) and, $\mathrm{H}$ values between $-20.25 \mathrm{~W} \mathrm{~m}^{-2}$ (Nov-2016) and $46.69 \mathrm{~W} \mathrm{~m}^{-2}$ (Nov-2017) (Fig. $7 \mathrm{~g}-1)$. LE and $\mathrm{H}$ values also decreased with the passage of HW in SG (Fig. $7 \mathrm{~g}-1)$. Decreases of $67 \mathrm{~W} \mathrm{~m}{ }^{2}$ 
in LE (Feb-2018) and $44.8 \mathrm{~W} \mathrm{~m}^{-2}$ in $\mathrm{H}$ (Jan-2017) were observed with the passage of HW in SG (Fig. $7 \mathrm{~g}-1)$.

In order to assess the contribution of HW events among years, the daily mean values of LE and $\mathrm{H}$ during these events and regular days appear in Figure 8 for both lakes. In LS, there was a significant contribution of HW, decreasing LE and H mean daily values (Fig. 8a). In 2015, LE and H decreased $78 \%$ and $254 \%$, respectively, compared to regular days, meanwhile, in 2016 a higher decrease of $96 \%$ and $671 \%$ was calculated because twice HW events were observed respect to 2015 (Fig. 8a). In SG the difference among years was not the same (Fig. 8b), with an increase in LE of the $25 \%$ and a decrease of 987\% in $\mathrm{H}$ for the period 2016-2017, meanwhile for 2017-2018, LE showed a decrease of $13 \%$ and $\mathrm{H} \mathrm{a}$ decrease of the $11 \%$. As in LS, in the first period, the number of HW events was twice as in the second one. However, the more significant changes occurred in 2016-2017 and could be associated with the inter-annual differences in rainfall (Table 2) which influences $\mathrm{RH}_{10}$ and Ta values; meanwhile, the second period presented the higher $\mathrm{U}_{10}$ values, which also explained the increase in LE and $\mathrm{H}$ observed for the regular days (Fig. 8b).

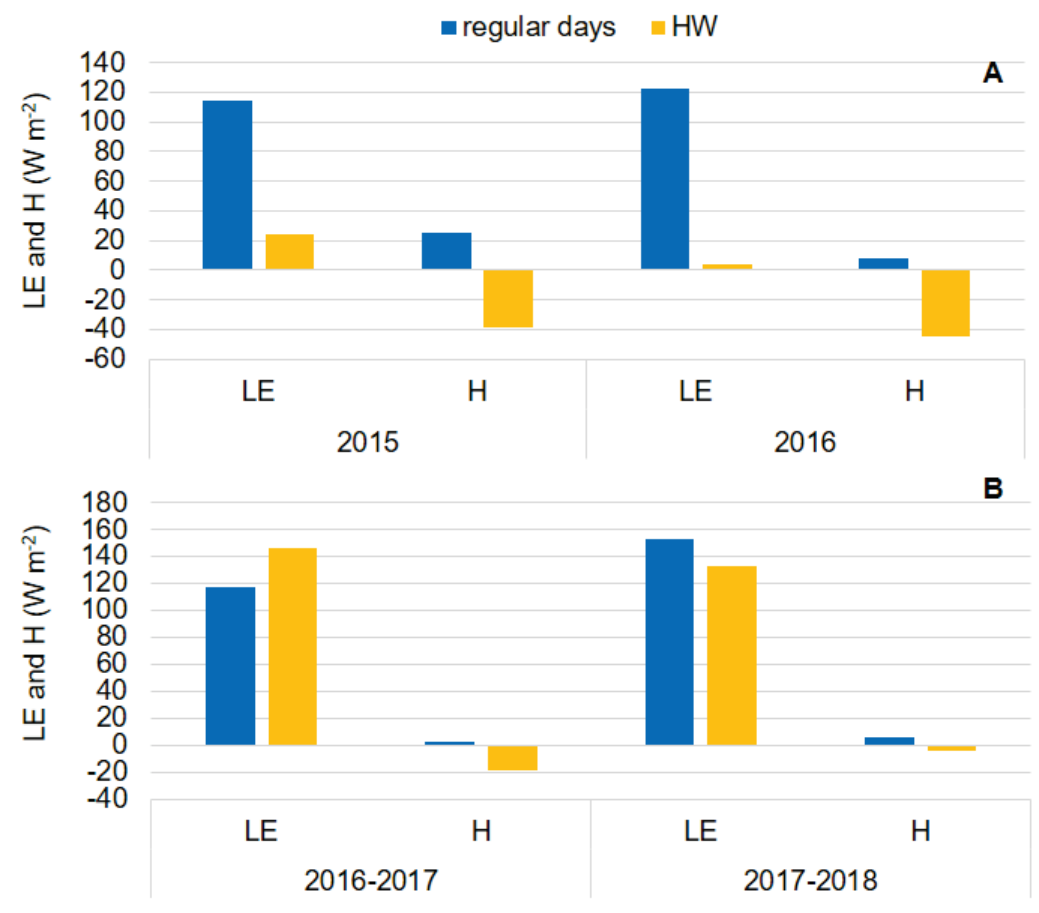

Figure 8. Mean daily $L E$ and $H$ values during regular days and heatwave events (HW) for both study periods in A: La Salada and B: Sauce Grande lakes during the study period.

\subsection{Driving forces of latent and sensible heat flux}

The results from the regression analysis are presented in Table 3. In LS, monthly LE was explained mainly by $\mathrm{U}_{10}$ changes (Table 3 ); meanwhile, monthly $\mathrm{H}$ was better explained by the product of $\mathrm{U}_{10} \times(\mathrm{Tw}-\mathrm{Ta})$ (Table 3$)$ with similar values for warmer months and the whole period. These results are following the strong $\mathrm{U}_{10}$ registered in the lake (Table 2, Fig. 2 and Fig. 4) and cited for the area (Alfonso et al., 2015, 2018; Aliaga et al., 2017).

In the case of $\mathrm{SG}$, monthly variance in $\mathrm{LE}$ was better explained by $\mathrm{RH}_{10}$, with $80 \%$ for the whole period, and $\mathrm{H}$ by the Tw-Ta difference, with $79 \%$ for warmer months. The difference between the whole period and the warmer months was higher in the case of the variance in LE and $\mathrm{H}$ explained by $\mathrm{U}_{10}$ (Table 3). The observed increase in $\mathrm{U}_{10}$ during the HW event is in accordance with these results (Fig. 
5c). A study in the Monte Hermoso beach registered the presence of sea breeze events for the beach and the area of influence, which includes the Sauce Grande lake (Huamantinco Cisneros and Piccolo, 2011). They described it as changes in wind speed and direction, with an influence on relative humidity and air temperature values. The predominance of sea breeze events was in summer, with higher mean wind speed values in December, January, and March, coinciding with the increment in $U_{10}$ found during the HW events and the relation between $U_{10}$ and $L E$ and $H$ values for the warmer months found in this study. The proximity of the sea to the SG and the presence of the sea breeze undoubtedly makes it difficult to understand the total of the processes that involve the turbulent flow of heat. Nevertheless, we need a more detailed analysis among the meteorological variables in SG and Monte Hermoso in the future for better conclusions about the relation of these events with the surface heat flux values. Other studies also attributed observed spikes in LE to substantial wind flow, which mixed the water and enhanced turbulent exchange (Blanken et al., 2003; Rouse et al., 2003; Shao et al., 2015).

Table 3. Linear regression coefficients between monthly latent heat flux $(L E)$ relative humidity $\left(R H_{10}\right)$, wind speed $\left(U_{10}\right)$ and, product of wind speed and relative humidity $\left(R H_{10} \times U_{10}\right)$; and between sensible heat flux $(H)$ and the difference in temperature between water and air $(T w-T a)$, wind speed $\left(U_{10}\right)$ and, the product of wind speed and the difference in temperature between water and air $\left(U_{10} \times(T w-T a)\right)$ in La Salada and Sauce Grande lakes For the entire study period and warmer months (October to March).

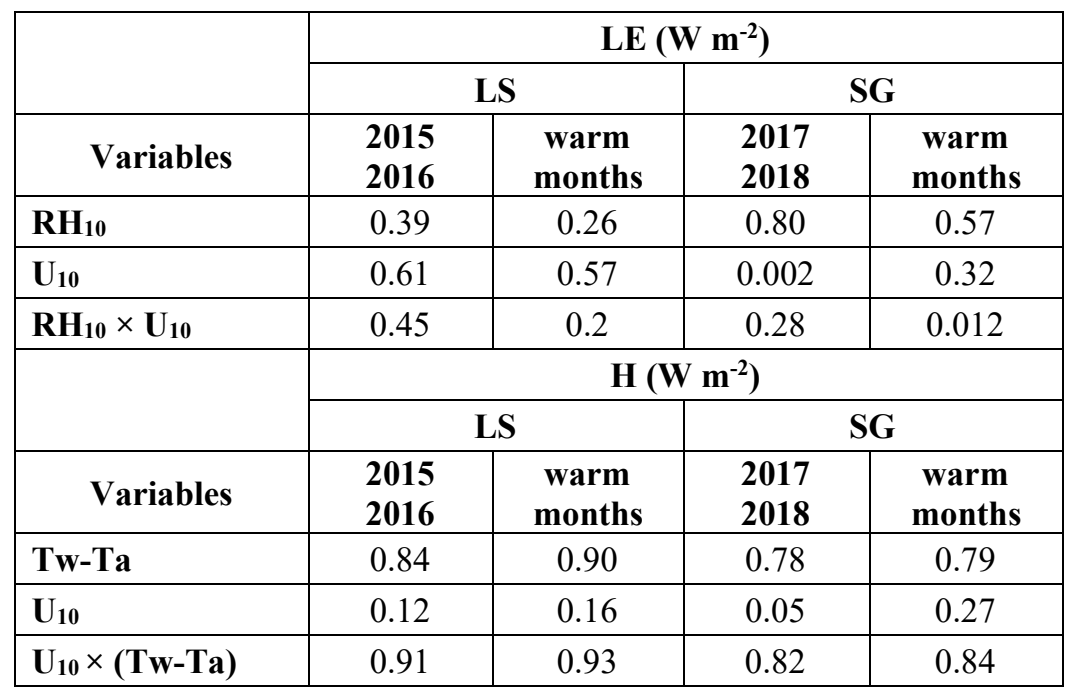

If we compared these results with other studies, similar relations are cited for $\mathrm{H}$ and the product between $\mathrm{U}_{10}$ and the Tw-Ta difference (Li et al., 2015). For LE, other investigations presented a better relationship with the product of $U_{10}$ and the difference between specific humidity in the water-air interface (Li et al., 2015) than for $\mathrm{U}_{10}$ by itself as in LS and SG lakes. The difference could be explained as other studies were developed in lakes where mean daily $U_{10}$ did not exceed the $10 \mathrm{~m} \mathrm{~s}^{-1}$ (Zhang and Liu, 2013; Li et al., 2015) whereas in this study, we found values greater than 20 and $14 \mathrm{~m} \mathrm{~s}^{-1}$ in LS and SG lakes respectively (Figs. 2 and 3), which also could explain the higher daily LE and $\mathrm{H}$ values cited here in comparison with other reports (Zhang and Liu, 2013; Li et al., 2015). Woolway et al. (2018) in a study developed in 45 lakes across different latitudinal and longitudinal gradients found that the $\mathrm{U}_{10}$ variation, which was the highest in winter, did not covary strongly with LE, H, or LE + H at seasonal timescales, meanwhile at diel timescales they found that $L E$ was related to $U_{10}$ diel changes. However, $\mathrm{H}$ was not, being the latter related to changes in the magnitude of the Tw-Ta.

Although the number of HW events was higher in the second period of study for both lakes, the mean Ta and Tw annual values remain similar between periods (Table1). However, we could register significant changes over LE and $\mathrm{H}$ fluxes on $\mathrm{HW}$ events, with the increment of Ta and Tw and significant changes in $\mathrm{U}_{10}$ and $\mathrm{HR}_{10}$ values in both lakes (Figs. 5, 6, 7, and 8). Audet et al. (2017) analyzed the 
effect of temperature on GHG emissions during HW events on shallow lakes and found a significant $\mathrm{HW}$-induced increase in $\mathrm{CO}_{2}$ emissions. Therefore, we should consider the effect of pulse events as $\mathrm{HW}$ when attempting to simulate the effect of global warming on ecosystem processes. Furthermore, previous studies reported that inland lakes have significant impacts on local and regional water and energy cycles (Long et al., 2007; Liu et al., 2012). According to Oki and Kanae (2006), evaporation from lakes returns about $60 \%$ of the annual lake precipitation to the atmosphere. Therefore, the observed decrease in LE and $\mathrm{H}$ with the occurrence of $\mathrm{HW}$ events, changes in the evaporation and precipitation cycles will be expected. As a consequence regional climate will be affected (Zhu et al., 2018), and notably, on shallow lakes, with changes in water level, physicochemical parameters, GHG emissions, nutrients concentrations and inland biological communities will be altered (Renella and Quirós, 2006; Fusé et al., 2016).

\subsection{Future perspectives in air temperature for the region based on climate change models}

For the 1998-2018 period, mean annual Ta presented a positive and significant trend in both sites. For LS, there was an annual increment of $0.8^{\circ} \mathrm{C}$ in Ta; meanwhile, for the SG, the increment was $0.2{ }^{\circ} \mathrm{C}$ (Table 4, Fig. 9). According to the CCSM4 model results, Ta will continue increasing in the near (2019-2039) and far (2079-2099) future under an RCP 8.5 scenario in both places (Table 4, Fig. 9). There will be expected a higher Ta increase for the SG region $\left(+1.1^{\circ} \mathrm{C}\right)$ than $\mathrm{LS}\left(+0.8^{\circ} \mathrm{C}\right)$. Under a mitigation scenario, with RCP 4.5, the trend results negative, but no statistically significant (Table 4, Fig. 9). These results are in accordance with previous studies in Argentina that project increases between 0.5 and $1.0^{\circ} \mathrm{C}$ for both RCP 4.5 and 8.5 scenarios (Barros et al., 2015).

According to these results and the studied effect of HW on LE and H lakes fluxes, we will expect more considerable amplitude changes in both variables with the increase in Ta. The later will increment the Tw-Ta, and consequently, the amplitude of change in H fluxes. Meanwhile, for LE, changes will also be expected as $\mathrm{Ta}$ and $\mathrm{RH}_{10}$ were negatively correlated in both lakes. According to the negative slope for the RCP 4.5 model, the impact of global warming on surface heat fluxes will be lesser if a mitigation effort in GHG emissions is applied; however, it was not statistically significant. Finally, if GHG emissions continue increasing, more considerable changes in LE and $\mathrm{H}$ fluxes will be expected, with negative consequences in shallow lakes as the evaporation process will increase. These results are in accordance with a study in the Southwest and Central Plains of Western North America, where an increase in drought severity is expected with climate change in the coming decades under moderate (RCP 4.5) and high (RCP 8.5) future emissions scenarios (Cook et al., 2015).

Table 4. Results from the Community Climate System Model 4 (CCSM4) and Mann- Kendall analysis for La Salada and Sauce Grande region present (1998-2018), near future (2019-2039) and far future air temperature time series (2079-2099).

\begin{tabular}{|l|c|c|c|c|}
\hline & \multicolumn{2}{|c|}{ La Salada } & \multicolumn{2}{c|}{ Sauce Grande } \\
\cline { 2 - 5 } & Significance & Trend & Significance & Trend \\
\hline $\mathbf{1 9 9 8 - 2 0 1 8}$ & 0.02 & 0.84 & 0.04 & 0.22 \\
\hline $\mathbf{2 0 1 9 - 2 0 3 9 ~ R C P ~ 4 . 5 ~}$ & 0.50 & -0.25 & 0.65 & -0.06 \\
\hline $\mathbf{2 0 1 9 - 2 0 3 9}$ RCP 8.5 85 & 0.03 & 0.77 & 0.01 & 1.05 \\
\hline $\mathbf{2 0 7 9 - 2 0 9 9}$ RCP 4.5 & 0.29 & -0.28 & 0.54 & -0.20 \\
\hline $\mathbf{2 0 7 9 - 2 0 9 9}$ RCP.8.5 & 0.00 & 0.91 & 0.00 & 1.13 \\
\hline
\end{tabular}




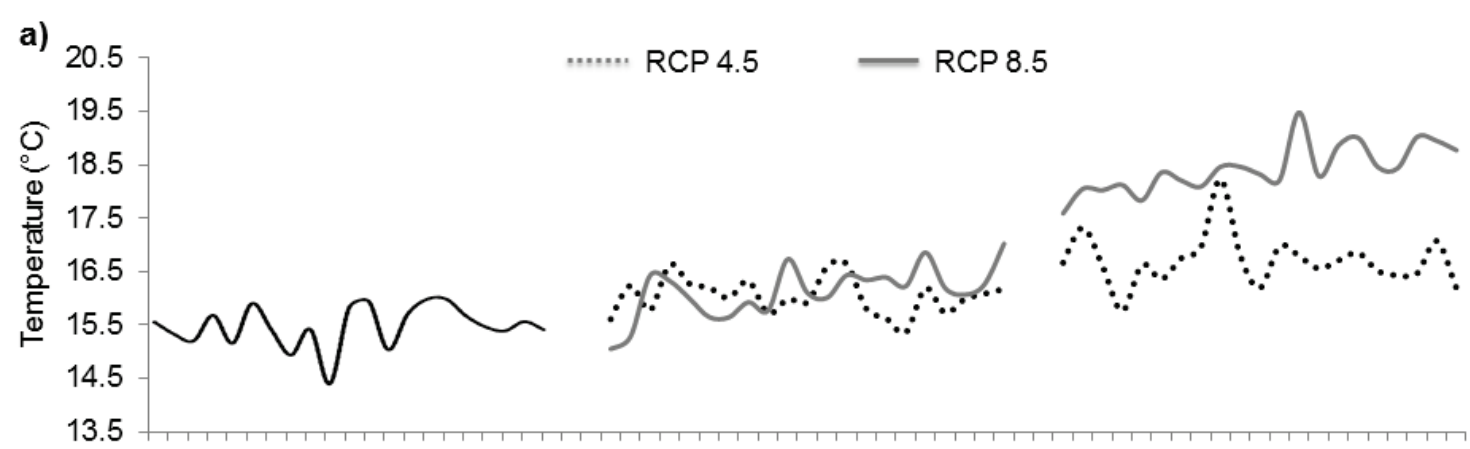

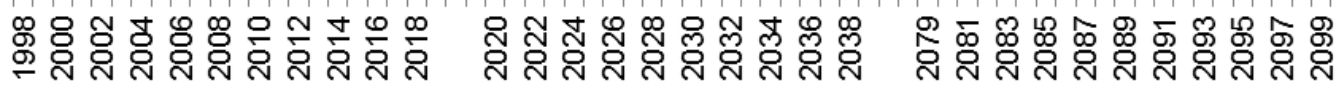

b)

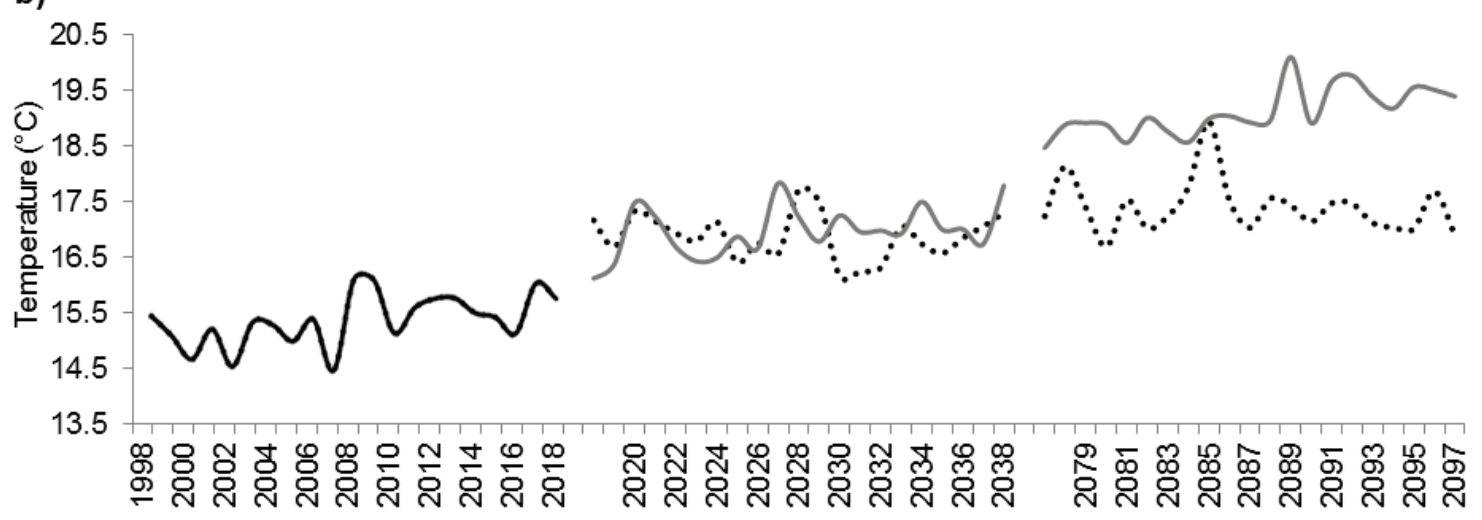

Figure 9. Trends in air temperature for La Salada and Sauce Grande region for the present (1998-2018), near future (2019-2039), and far future time series (2079-2099) under RCP 4.6 and RCP 8.5 models.

Also, a study for the United States found that extreme climate events as HW and annual extreme precipitations will increase under an RCP 8.5 scenario (Gao et al., 2012). Another study developed for the mid and high-altitude wetlands in China found that wetland distributions were predicted to decline remarkably over time under climate change scenarios with higher losses around agricultural lands (Zhao et al., 2018). For Argentina, the number and intensity of HW defined as at least three consecutive days over the $90^{\text {th }}$ percentile temperature of the 1961-1990 record has increased between 1961 and 2010 (Barros et al., 2015; Rusticucci et al., 2016), particularly those of short duration (3-5 days) as the cases studied here. Still, more detailed studies, according to projections under future climate scenarios, are needed.

\section{Conclusions}

Here we have analyzed for the first time the monthly, annual, and interannual variations of the surface latent and sensible heat on two shallow lakes from the Pampean Region. After the analysis of the effect of HW events, we found significant changes in LE and $\mathrm{H}$ heat fluxes of both lakes in response to the meteorological variables, with the increment of $\mathrm{Ta}$ and $\mathrm{Tw}$ and significant changes in $\mathrm{U}_{10}$ and $\mathrm{HR}_{10}$ values in both lakes. The main drivers of $\mathrm{LE}$ and $\mathrm{H}$ were wind speed and direction, relative humidity, and the difference between air and water temperature. Mean daily $\mathrm{H}$ values ranged between 309.4 to $200.5 \mathrm{~W} \mathrm{~m}^{-2}$ and -78.6 to $104.8 \mathrm{~W} \mathrm{~m}^{-2}$ in LS and SG, respectively. LE oscillated between -152 and $463.9 \mathrm{~W} \mathrm{~m}^{-2}$ and between -59.2 and $360.1 \mathrm{~W} \mathrm{~m}^{-2}$ in LS and SG, respectively. Both fluxes decreased with the passage of heatwaves events, presenting a high variation in its amplitude. Changes up to $96 \%$ in mean daily LE and $671 \%$ in mean daily $\mathrm{H}$ for LS and up to $25 \%$ in LE and $987 \%$ in $\mathrm{H}$ for SG were accounted in days with heatwaves respect to regular ones. Furthermore, the amplitude of changes and 
time of response to these events was different between lakes according to their geographical location, morphology, and the interannual variation in rainfall, highlighting the importance of water level and wind speed and direction on surface heat fluxes.

Also, we found increases in average air temperatures under global warming future scenarios for both lakes. According to these results and the expected change in the occurrence frequency of extreme events such as heatwaves (IPCC, 2014), we should expect substantial shifts in regional energy budget and hydrological balance in the regions with an abundance of shallow lakes. These results will contribute to the development of lake models, as well as in water resource management.

\section{Acknowledgments}

Grants from the network project PAMPA2 (CONICET), ANPCyT, Universidad Nacional del Sur (PGI 24/ G059), and the Inter American Institute for Global Change Research (IAI) CRN3038 (under US NSF Award GEO 1128040) supports the studies dealing with the article.

\section{References}

Alfonso, M.B., Brendel, A.S., Vitale, A.J., Seitz, C., Piccolo, M.C., Eduardo Perillo, G.M. 2018. Drivers of ecosystem metabolism in two managed shallow lakes with different salinity and trophic conditions: The Sauce Grande and La Salada Lakes (Argentina). Water (Switzerland) 10 (9), 1136. https://doi.org/10.3390/w10091136

Alfonso, M.B., Zunino, J., Piccolo, M.C. 2017. Impact of water input on plankton temporal dynamics from a managed shallow saline lake. Annales de Limnologie 53, 391-400. https://doi.org/10.1051/limn/2017023

Aliaga, V.S., Ferrelli, F., Piccolo, M.C. 2017. Regionalization of climate over the Argentine Pampas. International Journal of Climatology 37, 1237-1247. https://doi.org/10.1002/joc.5079

Arvola, L., George, G., Livingstone, D.M., Järvinen, M., Blenckner, T., Dokulil, M.T., Jennings E., Aonghusa, C.N., Nõges, P., Nõges, T., Weyhenmayer, G.A. 2009. The Impact of the Changing Climate on the Thermal Characteristics of Lakes. In: D.G. George (Ed.), The Impact of Climate Change on European Lakes, pp. 85-101. https://doi.org/10.1007/978-90-481-2945-4_6

Barros, V.R., Boninsegna, J.A., Camilloni, I.A., Chidiak, M., Magrín, G.O., Rusticucci, M. 2015. Climate change in Argentina: Trends, projections, impacts and adaptation. Wiley Interdisciplinary Reviews: Climate Change 6 (2), 151-169. https://doi.org/10.1002/wcc.316

Blanken, P.D., Rouse, W.R., Schertzer, W.M. 2003. Enhancement of evaporation from a large Northern Lake by the entrainment of warm, dry air. Journal of Hydrometeorology 4 (4), 680-693. https://doi.org/10.1175/1525-7541(2003)004<0680:EOEFAL>2.0.CO;2

Base de Datos Climáticos 3ra. Comunicación Nacional de la República Argentina a la Convención Marco de las Naciones Unidas sobre Cambio Climático, Centro de Investigaciones del Mar y la Atmósfera, CIMA. http://3cn.cima.fcen.uba.ar (accessed 10 October, 2019).

Cook, B.I., Ault, T.R., Smerdon, J.E. 2015. Unprecedented $21^{\text {st }}$ century drought risk in the American Southwest and Central Plains. Science Advances 1 (1), 1-8. https://doi.org/10.1126/sciadv.1400082

Davidson, T.A., Audet, J., Svenning, J.C., Lauridsen, T.L., Søndergaard, M., Landkildehus, F., larse, S.E., Jeppesen, E. 2015. Eutrophication effects on greenhouse gas fluxes from shallow-lake mesocosms override those of climate warming. Global Change Biology 21 (12), 4449-4463. https://doi.org/10.1111/gcb.13062

Di Rienzo J.A., Casanoves F., Balzarini M.G., Gonzalez L., Tablada M., Robledo C.W. 2018. Centro de Transferencia InfoStat, FCA, Universidad Nacional de Córdoba, Argentina. URL http://www.infostat.com.ar 
Diallo, I., Giorgi, F., Stordal, F. 2018. Influence of Lake Malawi on regional climate from a double-nested regional climate model experiment. Climate Dynamics 50 (9-10), 3397-3411. https://doi.org/10.1007/s00382-0173811-x

Diovisalvi, N., Salcedo Echeverry, G.E., Lagomarsino, L., Zagarese, H.E. 2015. Seasonal patterns and responses to an extreme climate event of rotifers community in a shallow eutrophic Pampean lake. Hydrobiologia 752 (1), 125-137. https://doi.org/10.1007/s10750-014-1909-2

Downing, J.A., Prairie, Y.T., Cole, J.J., Duarte, C.M., Tranvik, L.J., Striegl, R.G., et al. 2006. The global abundance and size distribution of lakes, ponds, and impoundments. Limnology and Oceanography 51 (5), 2388-2397. https://doi.org/10.4319/1o.2006.51.5.2388

Estación de Monitoreo Ambiental Costero, EMAC https://www.emac.iado-conicet.gob.ar/2019 (accessed 10 October 2019).

Fink, G., Schmid, M., Wüest, A. 2014. Large lakes as sources and sinks of anthropogenic heat: Capacities and limits. Water Resources Research 50 (9), 7285-7301. https://doi.org/10.1002/2014WR015509

Fusé, V.S., Priano, M.E., Williams, K.E., Gere, J.I., Guzmán, S.A, Gratton, R., Juliarena, M.P. 2016. Temporal variation in methane emissions in a shallow lake at a southern mid latitude during high and low rainfall periods. Environmental Monitoring and Assessment 188, 590. https://doi.org/10.1007/s10661-016-5601-z

Gao, Y., Fu, J.S., Drake, J.B., Liu, Y., Lamarque, J.F. 2012. Projected changes of extreme weather events in the eastern United States based on a high resolution climate modeling system. Environmental Research Letters 7 (4), 12 p. https://doi.org/10.1088/1748-9326/7/4/044025

Geraldi, A, Piccolo, M.C, Perillo, G.M.E. 2011. El rol de las lagunas bonaerenses en el paisaje pampeano. Ciencia Hoy 21 (123), 16-22. Retrieved from https://ri.conicet.gov.ar/handle/11336/21369

Havens, K., Paerl, H., Phlips, E., Zhu, M., Beaver, J., Srifa, A. 2016. Extreme weather events and climate variability provide a lens to how shallow lakes may respond to climate change. Water (Switzerland) 8 (6), 229. https://doi.org/10.3390/w8060229

Huamantinco Cisneros, M. A., Piccolo, M.C. 2011. Caracterización de la brisa de mar en el balneario de Monte Hermoso, Argentina. Estudios Geográficos 72 (271), 461-475. https://doi.org/10.3989/estgeogr.201118

Instituto Nacional de Tecnología Agropecuaria, INTA https://www.argentina.gob.ar/inta (accessed 10 October 2019).

IPCC, I. P. on C.C. 2014. Climate Change 2014: Synthesis Report. Contribution of Working Groups I, II and III.

Kendall, M. G. 1975. Rank Correlation Measures; Charles Griffin. London, 202 p.

Kraemer, B.M., Chandra, S., Dell, A.I., Dix, M., Kuusisto, E., Livingstone, D.M., Schladow, S.G., Silow, E., Sitoki, L.M., Tamatamah, R., McIntyre, P.B. 2017. Global patterns in lake ecosystem responses to warming based on the temperature dependence of metabolism. Global Change Biology 23 (5), 1881-1890. https://doi.org/10.1111/gcb.13459

Lagomarsino, L., Pérez, G.L., Escaray, R., Bustingorry, J., Zagarese, H.E. 2011. Weather variables as drivers of seasonal phosphorus dynamics in a shallow hypertrophic lake (Laguna Chascomús, Argentina). Fundamental and Applied Limnology 178 (3), 191-201. https://doi.org/10.1127/1863-9135/2011/0178-0191

Leira, M., Cantonati, M. 2008. Effects of water-level fluctuations on lakes: An annotated bibliography. Hydrobiologia 613, 171-184). https://doi.org/10.1007/s10750-008-9465-2

Li, Z., Lyu, S., Ao, Y., Wen, L., Zhao, L., Wang, S. 2015. Long-term energy flux and radiation balance observations over Lake Ngoring, Tibetan Plateau. Atmospheric Research 155, 13-25. https://doi.org/10.1016/j.atmosres.2014.11.019

Liu, H. P., Zhang, Q. Y., Dowler, G. 2012. Environmental controls on the surface energy budget over a large southern inland water in the United States: An analysis of one-year eddy covariance flux data. Journal of Hydrometeorology 13, 1893-1910. https://doi:10.1175/jhm-d-12-020.1

Long, Z., Perrie, W., Gyakum, J., Caya, D., Laprise, R. 2007. Northern lake impacts on local seasonal climate. Journal of Hydrometeorology 8, 881-896. https://doi:10.1175/jhm591.1 
Mann, H. B. 1945. Non-parametric Tests Against Trend. Econometrica $13 \quad(3), \quad 245$. https://doi.org/10.2307/1907187

Oki, T., Kanae, S. 2006. Global hydrological cycles and world water resources. Science 313, 1068-1072. https://doi:10.1126/science.1128845

Pohlert, T. 2018. Non-Parametric Trend Tests and Change-Point Detection, 1-18. http://docplayer.net/70194145Non-parametric-trend-tests-and-change-point-detection.html

Rennella, A., Quirós, R. 2006. The Effects of Hydrology on Plankton Biomass in Shallow Lakes of the Pampa Plain. Hydrobiologia 556, 181-191. https://doi.org/10.1007/s10750-005-0318-y

Rouse, W.R., Oswald, C.M., Binyamin, J., Blanken, P.D., Schertzer, W.M., Spence, C. 2003. Interannual and seasonal variability of the surface energy balance and temperature of central Great Slave Lake. Journal of Hydrometeorology 4 (4), 720-730. https://doi.org/10.1175/1525-7541(2003)004<0720:IASVOT>2.0.CO;2

Rusticucci, M., Kyselý, J., Almeira, G., Lhotka, O. 2016. Long-term variability of heat waves in Argentina and recurrence probability of the severe 2008 heat wave in Buenos Aires. Theoretical and Applied Climatology 124 (3-4), 679-689. https://doi.org/10.1007/s00704-015-1445-7

Sen, P.K. 1968. Estimates of the Regression Coefficient Based on Kendall's Tau. Journal of the American Statistical Association 63 (324), 1379-1389. https://doi.org/10.1080/01621459.1968.10480934

Servicio Meteorológico Nacional, SMN https://www.smn.gob.ar/ (accessed 10 October 2019).

Shao, C., Chen, J., Stepien, C.A., Chu, H., Ouyang, Z., Bridgeman, T.B., Czajkowski, K.P., Becker, R.H., John, R. 2015. Diurnal to annual changes in latent, sensible heat, and CO2 fluxes over a Laurentian Great Lake: A case study in Western Lake Erie. Journal of Geophysical Research G: Biogeosciences 120 (8), 1587 1604. https://doi.org/10.1002/2015JG003025

Tranvik, L.J., Downing, J.A., Cotner, J.B., Loiselle, S.A., Striegl, R.G., Ballatore, T.J., et al. 2009. Lakes and reservoirs as regulators of carbon cycling and climate. Limnology and Oceanography 54 (6 PART 2), 2298-2314. https://doi.org/10.4319/lo.2009.54.6_part_2.2298

Winder, M., Schindler, D.E. 2004. Climatic effects on the phenology of lake processes. Global Change Biology 10 (11), 1844-1856. https://doi.org/10.1111/j.1365-2486.2004.00849.x

Woolway, R.I., Jones, I.D., Feuchtmayr, H., Maberly, S.C. 2015a. A comparison of the diel variability in epilimnetic temperature for five lakes in the English Lake District. Inland Waters 5 (2), 139-154. https://doi.org/10.5268/IW-5.2.748

Woolway, R.I., Jones, I.D., Hamilton, D.P., Maberly, S.C., Muraoka, K., Read, J.S., Smyth, R.L., Winslow, L.A. 2015b. Automated calculation of surface energy fluxes with high-frequency lake buoy data. Environmental Modelling and Software 70, 191-198. https://doi.org/10.1016/j.envsoft.2015.04.013

Woolway, R. I., Verburg, P., Lenters, J. D., Merchant, C. J., Hamilton, D. P., Brookes, J., et al. 2018. Geographic and temporal variations in turbulent heat loss from lakes: A global analysis across 45 lakes. Limnology and Oceanography 63 (6), 2436-2449. https://doi.org/10.1002//no.10950

Wüest, A., Lorke, A. 2003. Small-scale hydrodynamics in lakes. Annual Review of Fluid Mechanics 35 (1), 373 412. https://doi.org/10.1146/annurev.fluid.35.101101.161220

Zhang, Q., Liu, H. 2013. Interannual variability in the surface energy budget and evaporation over a large southern inland water in the United States. Journal of Geophysical Research Atmospheres 118 (10), 4290-4302. https://doi.org/10.1002/jgrd.50435

Zhao, X., Liu, Y. 2018. Variability of Surface Heat Fluxes and Its Driving Forces at Different Time Scales Over a Large Ephemeral Lake in China. Journal of Geophysical Research: Atmospheres 123 (10), 4939-4957. https://doi.org/10.1029/2017JD027437

Zhu, C., Zeng, Y. 2018. Effects of urban lake wetlands on the spatial and temporal distribution of air PM10 and PM2.5 in the spring in Wuhan. Urban Forestry and Urban Greening 31, 142-156. https://doi.org/10.1016/j.ufug.2018.02.008 